\title{
The role of sodium phosphate cotransporters in ectopic calcification
}

\author{
Sergio Gonzalo, Ricardo Villa-Bellosta \\ Fundación Instituto de Investigación sanitaria, Fundación Jiménez Díaz, Madrid, Spain
}

\begin{abstract}
Phosphate plays a critical role in many vital cellular processes. Deviations from normal serum phosphate levels, including alterations in the extracellular phosphate/pyrophosphate ratio, can cause severe consequences, such as ectopic calcification. Cellular phosphate levels are tightly controlled by sodium phosphate cotransporters, underscoring their importance in cellular physiology. The role of sodium phosphate cotransporters in ectopic calcification requires further elucidation, taking into account their important role in the control of intracellular phosphate levels and the synthesis of ATP, the main source of extracellular pyrophosphate (a potent endogenous inhibitor of calcification). In this review, we discuss the roles of phosphate and pyrophosphate homeostasis in ectopic calcification, with a specific focus on phosphate transporters. We concentrate on the five known sodium-dependent phosphate transporters and review their localisation and regulation by external factors, and the effects observed in knockout studies and in naturally occurring mutations. (Endokrynol Pol 2019; 70 (6): 496-441)
\end{abstract}

Key words: phosphate; ectopic calcification; pyrophosphate; transporters; ATP

\section{Introduction}

\section{Phosphate}

Phosphate is required for many biological processes, including bioenergetics, metabolic regulation, cell signalling, cell proliferation, membrane integrity, and bone mineralisation [1, 2]. Organic phosphate that is ingested in foods is hydrolysed in the gastrointestinal tract, releasing inorganic phosphate. Aqueous phosphate exists in four forms, according to its triprotic equilibrium: 1 - trihydrogen phosphate $\left(\mathrm{H}_{3} \mathrm{PO}_{4}\right)$, 2 - dihydrogen phosphate ion $\left.\left(\mathrm{H}_{2} \mathrm{PO}_{4}^{-}\right), 3\right)$ hydrogen phosphate ion $\left(\mathrm{HPO}_{4}^{2-}\right)$, and 4$)$ phosphate ion $\left(\mathrm{PO}_{4}^{2-}\right)$. Phosphate is quite strong with respect to the first dissociation constant $\left(\mathrm{pK}_{\mathrm{a} 1}=2.1\right)$, moderately weak with respect to the second $\left(\mathrm{pK}_{\mathrm{a} 2}=6.9\right)$, and very weak with respect to the third $\left(\mathrm{pK}_{\mathrm{a} 3}=12.4\right)$ [3].

The phosphate concentration in the plasma is determined by its intestinal intake, excretion through the faeces, release from bone and soft tissue, and renal excretion. The principal means by which mammals achieve phosphate homeostasis is through the control of its reabsorption along the renal proximal tubule (PT) [4].

Given its critical roles in vital cellular processes, it is not surprising that deviations from normal serum phosphate concentrations can cause severe clinical disorders. A phosphate deficiency typically results in muscle weakness, rhabdomyolysis, impaired leukocyte function, and abnormal bone mineralisation, leading to rickets or osteomalacia [5-7]. Elevated serum phosphate concentrations contribute to the pathogenesis of secondary hyperparathyroidism in patients with chronic renal failure $[8,9]$.

Although systematically underestimated in national surveys, phosphorus intake seemingly continues to increase as a result of the growing consumption of highly processed foods, in particular restaurant meals, fast foods, and convenience foods [10]. While a high dietary intake of phosphate increases its renal excretion, a low dietary phosphate intake increases its renal reabsorption.

Phosphate homeostasis is also influenced by many other factors. For example, the renal excretion of phosphate is increased by parathyroid hormone (PTH), 1,25-OH2-vitamin D3, fibroblast growth factor 23 (FGF23), dopamine, and glucocorticoids, and is also increased during acidosis or hypokalaemia [7, 11]. Moreover, the renal reabsorption of phosphate is increased by insulin, insulin-like growth factor 1 (IGF1), 1,25-OH2-vitamin D3, and thyroid hormone, as well as during alkalosis [12-15]. 


\section{Phosphate and vascular calcification}

Elevated serum phosphate is a known inducer of vascular calcification $[16,17]$, which is associated with increased mortality [18].

Elevated serum phosphate significantly increases the risk of cardiovascular disease, regardless of pre-existing diseases such as chronic kidney disease (CKD) [19]. Increased serum phosphate concentrations are associated with the thickening of the carotid intima-media and are a strong contributing factor to arteriosclerosis in haemodialysis patients [20]. Furthermore, even when within the normal range, higher serum phosphate levels are associated with a higher prevalence of vascular and valvular calcification in people with moderate CKD [21].

Vascular calcification occurs in distinct layers of the aortic wall and is associated with specific pathologies. Intimal calcification is observed in atherosclerotic lesions, whereas medial calcification, "Monckeberg's medial sclerosis", occurs in the medial layer of the aortic wall and is associated with the elastic lamina [22, 23].

Over the last few years, a relationship between phosphate transport and the initiation of vascular calcification has been increasingly investigated [24]. Nevertheless, our understanding of calcification pathogenesis is far from complete. Several mechanisms that govern the initiation and progression of vascular calcification have been suggested, including passive and active processes [17, 25]. At physiological calcium and phosphate serum concentrations, calcium phosphate deposition (CPD) is a passive process that does not require cellular activity [26-29]. For example, calcification occurs more slowly than in hyperphosphataemic conditions, but it is highly pronounced after 21 days in a model without cellular activity [27]. Nevertheless, given that living cells do not calcify under physiological conditions, vascular smooth muscle cells (VSMCs) must participate in the process by synthesising several CPD inhibitors [27].

On the other hand, the reduced capacity of VSMCs to synthesise and secrete calcification inhibitors is the active process that contributes to vascular calcification $[16,17,28,30,31]$. In the extracellular fluids there are a range of endogenous low and high molecular weight inhibitors, including: 1 - low molecular weight (such as pyrophosphate, the major direct inhibitor of CPD formation and growth); and 2- small and medium-sized proteins (mainly calcium binding proteins such as osteopontin, fetuin-A, and matrix gla proteins) $[16,17]$. Other inhibitors in the second group include proteins involved in phosphate homeostasis regulation, which could play a potential indirect role as inhibitors of calcification (including osteoprotegerin, klotho/FGF23, and vitamin K) [16, 17].
An inverse and direct relationship between vascular calcification and bone mass has been established in a rat model of CKD receiving a long-term high-phosphorus diet, highlighting the complex relationship between calcification and phosphate homeostasis. After 20 weeks, the rats receiving the high-phosphorus diet displayed a significant increase in serum phosphorus, PTH, and creatinine, as well as aortic calcification and a decrease in bone mass [32].

\section{Phosphate transport and extracellular pyrophosphate metabolism}

Extracellular pyrophosphate is a potent inhibitor of vascular calcification and directly inhibits calcium phosphate crystal formation and growth in vitro and in vivo [31, 33-35]. Extracellular pyrophosphate is produced by the hydrolysis of extracellular ATP by ectonucleotide pyrophosphate/phosphodiesterase 1 (eNPP1) to form pyrophosphate and AMP (Fig. 1) [36], which is hydrolysed to form adenosine and phosphate via ecto-5' nucleotidase (NT5E, also called CD73). Moreover, pyrophosphate is degraded to phosphate by tissue non-specific alkaline phosphatase (TNAP). Both phosphate and adenosine can be recovered from the extracellular space for ATP generation by the mitochondria or through another metabolic pathway (Fig. 1). Phosphate is transported by sodium phosphate transporters that are described in the following section. Moreover, Ado is transported into cells by two known types of nucleoside transporters: concentrative nucleoside transporters (CNTs, SLC28) and equilibrative nucleoside transporters (ENTs, SLC29). Extracellular pyrophosphate metabolism begins with the transport of ATP to the extracellular milieu via an exocytotic mechanism and multiple types of membrane channels (Fig. 1). Studies show that loss-of-function mutations in eNPP1 [16], NT5E [37], and ENT1 [38] can also result in ectopic calcification. Therefore, the role of sodium-phosphate transporters (NPT) in the context of ectopic calcification is probably the main contributor to high intracellular phosphate and thus has implications for ATP synthesis [2].

\section{Sodium phosphate cotransporters}

Because of the negative electrochemical potential across the cell membrane, the movement of phosphate into the cell does not occur by simple diffusion. Sodium phosphate cotransporters enable cellular import, thereby controlling cellular Pi levels [13]. Three types of sodium-dependent phosphate transporter classes have been recognised in mammals: the NaPi-I (SLC17) family [39], the NaPi-II (SLC34) family [40], and the $\mathrm{NaPi}$-III (SLC20) family [41]. Although the NaPi-I family 


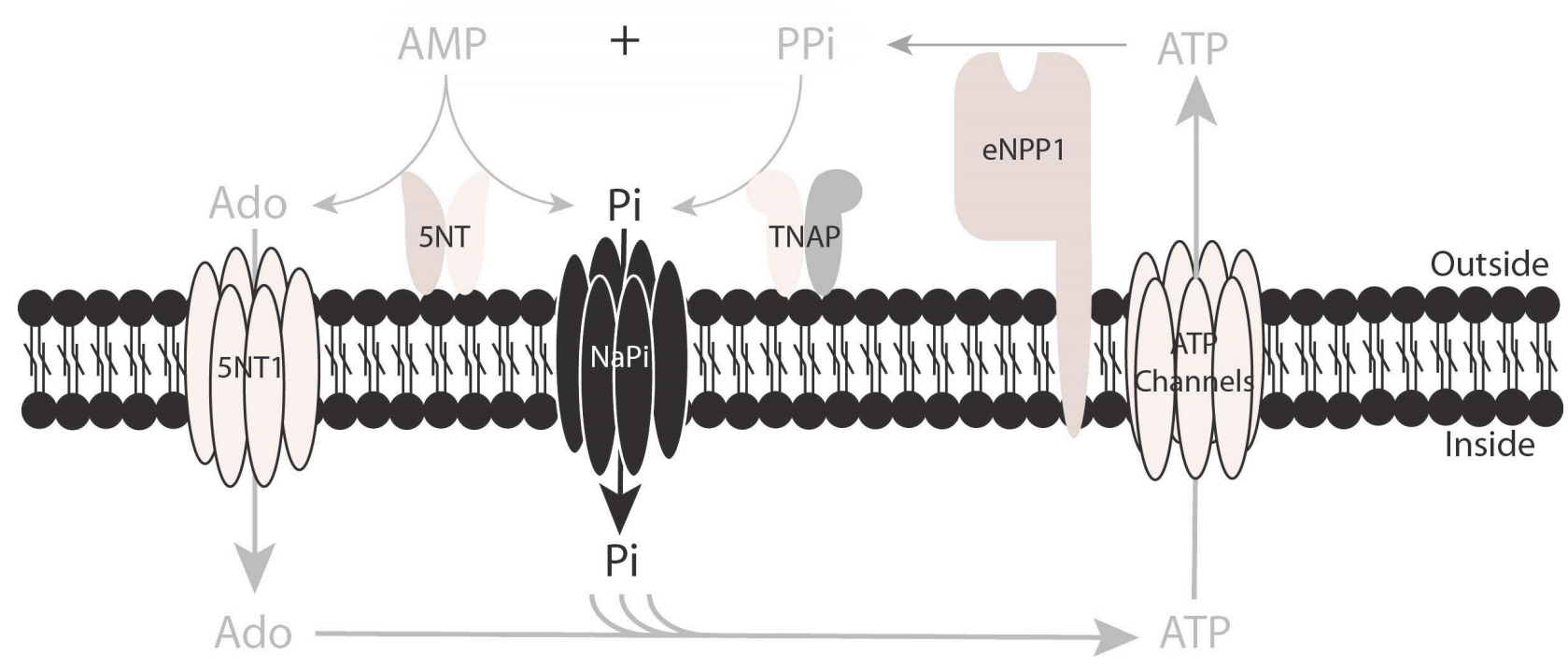

Figure 1. Role of sodium-phosphate cotransporters in the extracellular pyrophosphate metabolism. ATP is released by cells via exocytotic mechanisms and through multiple types of membrane channels. Ectonucleotide pyrophosphatase phosphodiesterase (eNPP) hydrolyses ATP, releasing pyrophosphate (PPi) and adenosine-5'-monophosphate (AMP). PPi is degraded to phosphate (Pi) by tissue non-specific alkaline phosphatase (TNAP). AMP is degraded to adenosine (Ado) and Pi via ecto-5'nucleotidase (5NT). Ado and Pi are recovered from the extracellular space by equilibrative nucleoside transporter 1 (ENT1) and sodium phosphate transporter (NaPi), respectively. ATP is generated in the mitochondria or through another metabolic pathway

members were originally identified as phosphate transporters, the relativity low affinity of the NaPi-I family members for phosphate suggested that they more readily transport organic and inorganic anions, rather than phosphate. By contrast, the NaPi-II and NaPi-III family members transport phosphate with high affinity $(\mathrm{Km} \approx 0.1 \mathrm{mmol} / \mathrm{L}$ or less) but display different affinities for $\mathrm{H}_{2} \mathrm{PO}_{4}^{-}$and $\mathrm{HPO}_{4}^{2-}$ ions [42-44].

In a very interesting review, Werner et al. [45] hypothesised that the original $\mathrm{NaPi}$-IIb-related gene was duplicated early in vertebrate development and that the appearance of NaPi-IIa correlated with the development of the mammalian nephron. NaPi-II and NaPi-III exhibit conserved structural features that are consistent with a prokaryotic origin.

The physiological importance of sodium phosphate cotransporters is underscored by the effects observed in knockout studies and in cases of naturally occurring mutations, as we review in the following sections and summarise in Table I.

\section{NaPi-II (SLC34 family)}

The NaPi-II (SLC34) family comprises three members: NaPi-IIa, NaPi-IIb, and NaPi-IIc [40]. They are high-affinity Pi transporters $\left(\mathrm{K}_{\mathrm{m}} \leq 100 \mu \mathrm{mol} / \mathrm{L}\right)$, exhibit a higher specificity for deprotonated phosphate $\left(\mathrm{HPO}_{4}^{2-}\right)$, and are specifically inhibited by phosphonoformic acid (PFA) [42].

All members of this family share a duplicated motif consisting of glutamine followed by a stretch of threo- nine or serine residues [46]. The two isoforms, NaPi-IIa and $\mathrm{NaPi}-\mathrm{Ill}$, have distinct differences in three hydrophilic regions. These include the two termini and a segment within the glycosylated extracellular loop [45]. There are differences in the protein/protein interactions between NaPi-IIa and NaPi-IIc. Fewer PDZ proteins interact with $\mathrm{NaPi}$-IIc compared with $\mathrm{NaPi}$-IIa. $\mathrm{NaPi}$-IIa interacts with NHERF1-4 $\left(\mathrm{Na}^{+} / \mathrm{H}^{+}\right.$exchanger regulatory factors 1-4), CAL ${ }^{\text {PIST }}$ (Golgi-associated PDZ and coiled-coil motif containing), and SHANK2E (SH3 multiple ankyrin repeat domains $2 \mathrm{E}$ ), while NaPi-IIc only interacts with NHERF1 and NHERF3 $[47,48]$.

$\mathrm{NaPi}-\mathrm{II}$ a and NaPi-IIb are electrogenic and translocate one net positive charge per transport cycle [49]. By contrast, $\mathrm{NaPi}$-IIc is electroneutral with no net charge translocation [50-52]. The members transport one divalent phosphate ion with an apparent affinity $\left(K_{0.5}^{\mathrm{Pi}}\right)$ of 10-70 mmol/L, together with two (NaPi-IIc) or three Na ions (NaPi-IIa and $\mathrm{NaPi}-\mathrm{IIb}$ ) with an apparent affinity $\left(K_{0.5}{ }^{\mathrm{Na}}\right)$ of $25-50 \mathrm{mmol} / \mathrm{L}[46]$.

\section{NaPi-IIa (SLC34A1)}

$\mathrm{NaPi}$-IIa is expressed predominantly in the renal PTs and the osteoclast basolateral membrane. Under normal conditions, NaPi-IIa is the major transporter for phosphate reabsorption in the PT [43].

A recent study reported that the loss-of-function of NaPi-IIa (Table 1) results in nephrocalcinosis and possibly in kidney insufficiency [53]. Interestingly, $\mathrm{NaPi}-\mathrm{II} a$ has also been identified in the brain [54]. It 
Table I. Sodium phosphate transporters. Expression and effects observed in knockout studies and in naturally occurring mutations (loss of function)

\begin{tabular}{|c|c|c|c|}
\hline Transporter & Expression & Loss of function & References \\
\hline \multirow{4}{*}{$\begin{array}{l}\text { NaPi-lla } \\
\text { (SLC34A1) }\end{array}$} & Kidney & Nephrocalcinosis, stone formation, kidney insufficiency & {$[53]$} \\
\hline & Bone (osteoclast) & Osteoporosis, rickets & {$[61]$} \\
\hline & Other & $\begin{array}{l}\text { Hypophosphataemia with hyperphosphaturia, reduced PTH, elevated 1,25-OH } \\
\text { vitamin D3 levels with secondary hypercalcaemia and hypercalciuria. }\end{array}$ & [61] \\
\hline & & Idiopathic infantile hypercalcaemia & \\
\hline \multirow{4}{*}{$\begin{array}{l}\text { NaPi-Ilb } \\
\text { (SLC34A2) }\end{array}$} & Small intestine & $\begin{array}{l}\text { Phosphaturia, higher expression of NaPi-lla, higher } \mathrm{Na} / \mathrm{Pi} \text { cotransport activity } \\
\text { in renal BBMVs, reduced plasma levels of intact FGF23 }\end{array}$ & {$[66]$} \\
\hline & Testis & Testicular calcification & {$[64]$} \\
\hline & Lung & Pulmonary alveolar microlithiasis & {$[64]$} \\
\hline & Full KO & Lethal & {$[63]$} \\
\hline \multirow{2}{*}{$\begin{array}{l}\text { NaPi-llc } \\
\text { (SLC34A3) }\end{array}$} & Kidney & $\begin{array}{l}\text { Higher levels of Pi in plasma and urine as well as circulating levels of parathyroid } \\
\text { hormone, FGF23; vitamin D3 levels remained unchanged (in mice) }\end{array}$ & {$[70]$} \\
\hline & Full KO & Hypercalcaemia, hypercalciuria, and increased $1,25-0 \mathrm{H}$ vitamin D3 levels & {$[69]$} \\
\hline \multirow{3}{*}{$\begin{array}{l}\text { Pit-1 } \\
\text { (SLC20A1) }\end{array}$} & VSMCs & Not produced: ectopic calcification & {$[95]$} \\
\hline & Chondrocytes & Cartilage calcification & {$[92]$} \\
\hline & Full KO & Lethal & {$[94]$} \\
\hline \multirow{3}{*}{$\begin{array}{l}\text { Pit-2 } \\
\text { (SLC20A2) }\end{array}$} & Brain & Brain calcification & {$[97,98]$} \\
\hline & Placenta & Placental calcification & {$[96]$} \\
\hline & Full KO & Foetal growth restriction, subviability ( $\sim 50 \%$ death rate prior to weaning age in mice) & {$[96]$} \\
\hline
\end{tabular}

is hypothesised that NaPi-IIa in the brain is involved in phosphate sensing, which consequently suggests that the renal expression of NaPi-IIa may be centrally regulated [55].

Recently, it was demonstrated that NaPi-IIa is the only SLC34 member expressed during RANKL-induced osteoclast differentiation but is dispensable for osteoclast differentiation and bone resorption [56].

Within the first four hours after ingestion of a low-phosphate diet, brush border $\mathrm{Na}^{+} / \mathrm{Pi}$ cotransport increases due to a rise in NaPi-IIa levels [57, 58]. By contrast, NaPi-IIa abundance changes quickly in response to a high-phosphate intake (in less than one hour) throughout the PT. In this case, phosphate internalisation occurs in a microtubule-independent way, and molecules are targeted to the lysosome via endosomes $[59,60]$.

The global knockout of NaPi-IIa in mice results in skeletal abnormalities, hypophosphataemia with hyperphosphaturia, reduced PTH, and elevated 1,25-OH vitamin D3 levels with secondary hypercalcaemia and hypercalciuria (Tab. I). Moreover, Na-dependent phosphate uptake in brush border membrane (BBM) preparations from these mice is reduced by $70 \%$ compared with that in the tissue from normal animals [61].

Recently, it was shown that oestrogen specifically down-regulates NaPi-IIa, but not NaPi-IIc or Pit-2, in the kidney cortex through the activation of both oestrogen receptor isoforms $(\mathrm{ER} \alpha$ and $\operatorname{ER} \beta)$ in the rat kidney PT [62].

\section{NaPi-IIb (SLC34A2)}

$\mathrm{NaPi}-\mathrm{IIb}$ expression has been detected in the small intestine, lungs, mammary glands, salivary gland, thyroid gland, testis, and liver [40].

Global NaPi-IIb knockout is lethal [63], but NaPi-IIb loss-of-function is associated with alveolar calcification in middle age $[64,65]$, and sometimes calcification in other organs, such as the testis (Tab. I) [64]. Intestine-specific ablation of $\mathrm{NaPi}-\mathrm{IIb}$ in mice results in viable pups with normal growth, but increased excretion of phosphate through the faeces and a complete absence of sodium-phosphate cotransport activity in $\mathrm{BBM}$ vesicles (BBMVs) isolated from the ileum were observed. Notably, the absence of this transporter is fully compensated in adult females by a mechanism involving the bone-kidney axis [66].

It is likely that $\mathrm{NaPi}-\mathrm{IIb}$ mediates secondary active phosphate accumulation at the basolateral membrane and consequently reverses phosphate flux in mammalian secretory tissue [45].

\section{NaPi-IIc (SLC34A3)}

$\mathrm{NaPi}$-IIc is expressed in the kidney and has been described a having growth-related functions [51, 52]. It is found in the BBM of the early PT (S1 segment) of 
juxtamedullary nephrons. During phosphate depletion, $\mathrm{NaPi}$-IIc is also detected in the early PT of superficial nephrons [51, 67, 68].

The global knockout of NaPi-IIc in mice results in hypercalcaemia, hypercalciuria, and increased $1,25-\mathrm{OH}$ vitamin D3 levels (Tab. I) [69]. However, unlike in humans, the kidney-specific deletion of NaPi-IIc in mice does not disturb phosphate homeostasis, strongly suggesting an extrarenal role of $\mathrm{NaPi}$-IIc in the intestine and/or bone [70] (Tab. I).

The role of NaPi-IIc in bone physiology is not clear. Although it regulates calcium metabolism [69], it was recently described to have no role in osteoclast differentiation and function [56].

\section{NaPi-III (SLC20 family)}

Although NaPi-IIa and NaPi-IIc are the principal mediators of renal phosphate reabsorption, significant phosphate reabsorption remains in both knockout animals. This observation suggested the existence of other phosphate transporters: the SLC20 family. This family, also called NaPi-III, comprises two members: Pit-1 and Pit-2(41). These were originally identified as cell surface receptors for gibbon ape leukaemia virus (Glvr-1) and rat amphotropic leukaemia virus (Ram-1), respectively [71, 72].

Pit- 1 and Pit- 2 mediate the movement of phosphate ions across the cell membrane $[73,74]$ and are ubiquitously expressed. VSMCs express both phosphate transporters, but Pit-1 [24, 75] is more abundant than Pit-2 [76].

Pit-1 and Pit-2 are electrogenic, with a coupling stoichiometry of $>1 \mathrm{Na}^{+}$ions per Pi ion cotransported [41], but unlike NaPi-IIa and NaPi-IIc, they display a preference for monovalent phosphate and a reduced sensitivity to $\mathrm{pH}$ and the phosphate transport inhibitor PFA [73, 77].

The current model predicts a 12 transmembrane domains structure, but in contrast to the SLC34 family proteins, the $\mathrm{N}$ - and C-termini are both extracellular $[78,79]$.

A recent study proposes that Pit- 1 and Pit- 2 are the main transporters responsible for sodium-driven phosphate uptake in osteoclasts [56]. In fact, their involvement in vascular calcification $[76,80,81]$ and bone mineralisation [82] suggests a key role in vascular and skeletal pathologies VSMCs have both Na-dependent and Na-independent phosphate transport components with a similar kinetic behaviour, but only Na-coupled saturable uptake can be attributed to the expression of both Pit-1 and Pit-2 [73, 76]. Recently, Pit-1 and Pit-2 gene expression was shown to be upregulated in Npt2a-null mice during metabolic acidosis, suggesting a possible compensatory role for SLC20 proteins [83].
The expression level and thereby the transport activity of the NaPi-III protein family are regulated by the extracellular phosphate levels [84-87]. For instance, phosphate uptake and Pit-1 and Pit-2 mRNA levels were higher in $208 \mathrm{~F}$ rat fibroblasts grown in a Pi-free medium. Similarly, in human embryonic kidney cells, phosphate deprivation stimulated Pit-1-mediated phosphate uptake [88], and an increase in Pit-2 mRNA and protein levels was reported for two osteosarcoma cell lines [84]. We showed that rats receiving a long-term high-phosphate $(1.2 \%)$ diet exhibit a significant decrease in Pit-2 protein expression in the kidney compared with that of rats maintained on a long-term low-phosphate $(0.1 \%)$ diet [89].

\section{Pit-1 (SLC20A1)}

Pit-1 mRNA expression is highest in osteoblasts, VSMCs, and bone marrow $[73,76,82]$. Pit-1 plays a critical role in cartilage calcification and the regulation of apoptosis and cell proliferation [90-93].

Various transport-independent functions of Pit-1 have been described that may help explain the role of Pit-1 in VC: the transporter is involved not only in the modulation of cell proliferation [91] but also in the regulation of $\mathrm{TNF} \alpha$-induced apoptosis and mitogen-activated protein kinase (MAPK) activation [91], which are related to calcification pathogenesisThe deletion of Pit- 1 in the mouse suggests that Pit-1 plays an essential function in liver development (Tab. I) [94]. The targeted deletion of Pit-1 in VSMCs in the mouse did not induce aortic calcification due to compensatory regulation by Pit-2 [95]. Moreover, loss of function in Pit-1 results in cartilage calcification (Tab. I) [92]. In contrast to Pit-2, a global Pit-1 knockout is embryonically lethal in mice (Tab. I) [94].

\section{Pit-2 (SLC20A2)}

The expression of Pit- 2 is highest in VSMCs, liver, heart, and brain, and it is also localised in the BBM of the PT epithelia $[41,73,89]$. Recently, it was reported that Pit-2 is required for normal placental function and that its deficiency results in foetal growth restriction and placental calcification [96].

Pit-2 mutations have been identified in patients with familial idiopathic basal ganglia calcification(FIBCG) [97], suggesting that the functional loss of phosphate transport can produce a decrease in the synthesis of CPD inhibitors and a local phosphate accumulation in the extracellular matrix, both contributing to the consequent increase of CPD (Tab. I). No abnormalities in serum electrolytes or calciotropic hormones and no obvious bone phenotype have been described in FIBCG patients. Pit-2 KO mice recapitulate the human disease in that they exhibit basal ganglia calcification [98]. 
Previous studies reported that PiT-2 is significantly down-regulated in the BBM in rats switched from a long-term low-Pi to a high-Pi diet after only 24 hours [89]. For the reverse dietary regime, PiT-2 displayed a slower adaptive trend. These findings suggest that PiT-2, until now considered to be a ubiquitously expressed phosphate housekeeping transporter, is a novel mediator of phosphate reabsorption in the PT during acute phosphate deprivation and acidosis conditions [43], and that it displays a different adaptive time course than NaPi-IIa and NaPi-IIc [89].

\section{The influence of $\mathrm{pH}$ on $\mathrm{NaPi}$ cotransporters}

One of the most important factors that affects $\mathrm{NaPi}$ transporters is the $\mathrm{pH}$. NaPi-IIa and NaPi-IIc activity is highest at alkaline $\mathrm{pH}$ levels, whereas Pit-1 and Pit-2 are maximally activated at low $\mathrm{pH}$ levels [43]. In addition, while chronic adaptation to a low-phosphate diet increases the expression of NaPi-IIa, NaPi-IIc, and Pit-2 protein and increases the phosphate transport $\mathrm{V}_{\text {max }}$ in BBMVs at $\mathrm{pH} 7.5$, the increase in transport is minimised when uptake takes place at pH 6.0 (i.e. when Pit-2 is maximally activated but NaPi-IIa and NaPi-IIc are inhibited by $90 \%$ ). In contrast to the renal type II isoform, type IIb-associated sodium-phosphate cotransport was less dependent on the $\mathrm{pH}$ and was slightly higher at more acidic $\mathrm{pH}$ values $[43,99]$. These biochemical differences suggest that each transporter has a specific role in the PT to avoid physiological redundancy

\section{Conclusions and future perspectives}

The maintenance of appropriate phosphate homeostasis is vital to avoid negative health consequences, such as calcification in soft tissues. Sodium phosphate cotransporters are key players in these processes, and their importance has been underscored in different studies demonstrating the effects of the alteration in their expression and loss of function (Tab. I).

Understanding sodium phosphate cotransporter function and regulation is very useful for improving the treatment and prevention of ectopic calcification, because they play critical roles in maintaining phosphate homeostasis and in the intracellular synthesis of ATP. Moreover, we propose that not only phosphate homeostasis but also pyrophosphate homeostasis must be taken into account in the design of therapeutic strategies for ectopic calcification [25].

\section{Funding}

R.V.B. is supported by grants from the Spanish Ministerio de Economia y Competitividad (SAF-2014-60699-JIN) and Progeria Research Foundation (PRF2016-68).

\section{Disclosures}

No conflicts of interest, financial or otherwise, are declared by the authors.

\section{References}

1. Hubbard SR, Till JH. Protein tyrosine kinase structure and function. Annu Rev Biochem. 2000; 69: 373-398, doi: 10.1146/annurev.biochem.69.1.373, indexed in Pubmed: 10966463.

2. Berndt T, Kumar R. Novel mechanisms in the regulation of phosphorus homeostasis. Physiology (Bethesda). 2009; 24: 17-25, doi: 10.1152/physiol.00034.2008, indexed in Pubmed: 19196648.

3. Villa-Bellosta R. Vascular Calcification Revisited: A New Perspective for Phosphate Transport. Curr Cardiol Rev. 2015; 11(4): 341-351, doi: 10.217 4/1573403X11666150805120505, indexed in Pubmed: 26242187.

4. Murer H, Hernando N, Forster I, et al. Proximal tubular phosphate reabsorption: molecular mechanisms. Physiol Rev. 2000; 80(4): 1373-1409, doi: 10.1152/physrev.2000.80.4.1373, indexed in Pubmed: 11015617.

5. Knochel JP. The pathophysiology and clinical characteristics of severe hypophosphatemia. Arch Intern Med. 1977; 137(2): 203-220, indexed in Pubmed: 836118.

6. Knochel JP, Barcenas C, Cotton JR, et al. Hypophosphatemia and rhabdomyolysis. Trans Assoc Am Physicians. 1978; 91: 156-168, indexed in Pubmed: 754389.

7. Shaikh A, Berndt T, Kumar R. Regulation of phosphate homeostasis by the phosphatonins and other novel mediators. Pediatr Nephrol. 2008; 23(8): 1203-1210, doi: 10.1007/s00467-008-0751-z, indexed in Pubmed: 18288501.

8. McIntyre CW. New developments in the management of hyperphosphatemia in chronic kidney disease. Semin Dial. 2007; 20(4): 337-341, doi: 10.1111/j.1525-139X.2007.00306.x, indexed in Pubmed: 17635825.

9. Slatopolsky E, Bricker NS. The role of phosphorus restriction in the prevention of secondary hyperparathyroidism in chronic renal disease. Kidney Int. 1973; 4(2): 141-145, doi: 10.1038/ki.1973.92, indexed in Pubmed: 4355426.

10. Calvo MS, Uribarri J. Public health impact of dietary phosphorus excess on bone and cardiovascular health in the general population. Am J Clin Nutr. 2013; 98(1): 6-15, doi: 10.3945/ajcn.112.053934, indexed in Pubmed: 23719553.

11. Berndt TJ, Schiavi S, Kumar R. "Phosphatonins” and the regulation of phosphorus homeostasis. Am J Physiol Renal Physiol. 2005 289(6): F1170-F1182, doi: 10.1152/ajprenal.00072.2005, indexed in Pubmed: 16275744 .

12. Bergwitz C, Jüppner H. Regulation of phosphate homeostasis by PTH, vitamin D, and FGF23. Annu Rev Med. 2010; 61: 91-104, doi: 10.1146/annurev.med.051308.111339, indexed in Pubmed: 20059333.

13. Biber J, Hernando N, Forster I. Phosphate transporters and their function. Annu Rev Physiol. 2013; 75: 535-550, doi: 10.1146/annurev-physiol-030212-183748, indexed in Pubmed: 23398154.

14. Breusegem SY, Takahashi H, Giral-Arnal H, et al. Differential regulation of the renal sodium-phosphate cotransporters NaPi-IIa, NaPi-IIc, and PiT-2 in dietary potassium deficiency. Am J Physiol Renal Physiol. 2009; 297(2): F350-F361, doi: 10.1152/ajprenal.90765.2008, indexed in Pubmed: 19493963.

15. Murer $\mathrm{H}, \mathrm{Hernando} \mathrm{N}$, Forster I, et al. Regulation of Na/Pi transporter in the proximal tubule. Annu Rev Physiol. 2003; 65: 531-542, doi: 10.1146/annurev.physiol.65.042902.092424, indexed in Pubmed: 12517995.

16. Rutsch F, Nitschke Y, Terkeltaub R. Genetics in arterial calcification: pieces of a puzzle and cogs in a wheel. Circ Res. 2011; 109(5): 578-592, doi: 10.1161/CIRCRESAHA.111.247965, indexed in Pubmed: 21852556.

17. Shanahan CM, Crouthamel MH, Kapustin A, et al. Arterial calcification in chronic kidney disease: key roles for calcium and phosphate. Circ Res. 2011; 109(6): 697-711, doi: 10.1161/CIRCRESAHA.110.234914, indexed in Pubmed: 21885837.

18. Pradelli D, Faden G, Mureddu G, et al. Impact of aortic or mitral valve sclerosis and calcification on cardiovascular events and mortality: a meta-analysis. Int J Cardiol. 2013; 170(2): e51-e55, doi: 10.1016/j. ijcard.2013.10.081, indexed in Pubmed: 24231061.

19. Dhingra R, Sullivan LM, Fox CS, et al. Relations of serum phosphorus and calcium levels to the incidence of cardiovascular disease in the community. Arch Intern Med. 2007; 167(9): 879-885, doi: 10.1001/archinte.167.9.879, indexed in Pubmed: 17502528.

20. Ishimura E, Taniwaki H, Tabata T, et al. Cross-sectional association of serum phosphate with carotid intima-medial thickness in hemodialysis patients. Am J Kidney Dis. 2005; 45(5): 859-865, doi: 10.1053/j. ajkd.2005.02.008, indexed in Pubmed: 15861351.

21. Adeney KL, Siscovick DS, Ix JH, et al. Association of serum phosphate with vascular and valvular calcification in moderate CKD. J Am Soc Nephrol. 2009; 20(2): 381-387, doi: 10.1681/ASN.2008040349, indexed in Pubmed: 19073826. 
22. Rocha-Singh KJ, Zeller T, Jaff MR. Peripheral arterial calcification: prevalence, mechanism, detection, and clinical implications. Catheter Cardiovasc Interv. 2014; 83(6): E212-E220, doi: 10.1002/ccd.25387, indexed in Pubmed: 24402839.

23. Urry DW. Neutral sites for calcium ion binding to elastin and collagen: a charge neutralization theory for calcification and its relationship to atherosclerosis. Proc Natl Acad Sci U S A. 1971; 68(4): 810-814, doi: 10.1073/pnas.68.4.810, indexed in Pubmed: 4251554.

24. Jono S, McKee MD, Murry CE, et al. Phosphate regulation of vascular smooth muscle cell calcification. Circ Res. 2000; 87(7): E10-E17, doi: 10.1161/01.res.87.7.e10, indexed in Pubmed: 11009570.

25. Villa-Bellosta R, Egido J. Phosphate, pyrophosphate, and vascular calcification: a question of balance. Eur Heart J. 2017; 38(23): 1801-1804, doi: 10.1093/eurheartj/ehv605, indexed in Pubmed: 26546599.

26. Johnsson MS, Nancollas GH. The role of brushite and octacalcium phosphate in apatite formation. Crit Rev Oral Biol Med. 1992; 3(1-2): 61-82, indexed in Pubmed: 1730071.

27. Villa-Bellosta R, Sorribas V. Calcium phosphate deposition with normal phosphate concentration. Role of pyrophosphate. Circ J. 2011; 75(11): 2705-2710, doi: 10.1253/circj.cj-11-0477, indexed in Pubmed: 21799271.

28. Villa-Bellosta R, Millan A, Sorribas V. Role of calcium-phosphate deposition in vascular smooth muscle cell calcification. Am J Physiol Cell Physiol. 2011; 300(1): C210-C220, doi: 10.1152/ajpcell.00229.2010, indexed in Pubmed: 20881235.

29. Schinke T, Karsenty G. Vascular calcification - a passive process in need of inhibitors. Nephrol Dial Transplant. 2000; 15(9): 1272-1274, doi: 10.1093/ndt/15.9.1272, indexed in Pubmed: 10978374.

30. Sage AP, Lu J, Tintut Y, et al. Hyperphosphatemia-induced nanocrystals upregulate the expression of bone morphogenetic protein-2 and osteopontin genes in mouse smooth muscle cells in vitro. Kidney Int. 2011; 79(4): 414-422, doi: 10.1038/ki.2010.390, indexed in Pubmed: 20944546.

31. Villa-Bellosta R, Rivera-Torres J, Osorio FG, et al. Defective extracellular pyrophosphate metabolism promotes vascular calcification in a mouse model of Hutchinson-Gilford progeria syndrome that is ameliorated on pyrophosphate treatment. Circulation. 2013; 127(24): 2442-2451, doi: 10.1161/CIRCULATIONAHA.112.000571, indexed in Pubmed: 23690466.

32. Román-García P, Carrillo-López N, Fernández-Martín JL, et al. High phosphorus diet induces vascular calcification, a related decrease in bone mass and changes in the aortic gene expression. Bone. 2010; 46(1): 121-128, doi: 10.1016/j.bone.2009.09.006, indexed in Pubmed: 19772957.

33. O'Neill WC, Lomashvili KA, Malluche HH, et al. Treatment with pyrophosphate inhibits uremic vascular calcification. Kidney Int. 2011; 79(5): 512-517, doi: 10.1038/ki.2010.461, indexed in Pubmed: 21124302.

34. Riser BL, Barreto FC, Rezg R, et al. Daily peritoneal administration of sodium pyrophosphate in a dialysis solution prevents the development of vascular calcification in a mouse model of uraemia. Nephrol Dial Transplant. 2011; 26(10): 3349-3357, doi: 10.1093/ndt/gfr039, indexed in Pubmed: 21398365.

35. Villa-Bellosta R, Sorribas V. Phosphonoformic acid prevents vascular smooth muscle cell calcification by inhibiting calcium-phosphate deposition. Arterioscler Thromb Vasc Biol. 2009; 29(5): 761-766, doi: 10.1161/ATVBAHA.108.183384, indexed in Pubmed: 19213941.

36. Villa-Bellosta R, Wang X, Millán JL, et al. Extracellular pyrophosphate metabolism and calcification in vascular smooth muscle. Am J Physiol Heart Circ Physiol. 2011; 301(1): H61-H68, doi: 10.1152/ajpheart.01020.2010, indexed in Pubmed: 21490328

37. St Hilaire C, Ziegler SG, Markello TC, et al. NT5E mutations and arterial calcifications. N Engl J Med. 2011; 364(5): 432-442, doi: 10.1056/NEJMoa0912923, indexed in Pubmed: 21288095.

38. Warraich S, Bone DBJ, Quinonez D, et al. Loss of equilibrative nucleoside transporter 1 in mice leads to progressive ectopic mineralization of spinal tissues resembling diffuse idiopathic skeletal hyperostosis in humans. J Bone Miner Res. 2013; 28(5): 1135-1149, doi: 10.1002/jbmr.1826, indexed in Pubmed: 23184610.

39. Reimer RJ, Edwards RH. Organic anion transport is the primary function of the SLC17/type I phosphate transporter family. Pflugers Arch. 2004; 447(5): 629-635, doi: 10.1007/s00424-003-1087-y, indexed in Pubmed: 12811560.

40. Wagner CA, Hernando N, Forster IC, et al. The SLC34 family of sodium-dependent phosphate transporters. Pflugers Arch. 2014; 466(1): 139-153, doi: 10.1007/s00424-013-1418-6, indexed in Pubmed: 24352629.

41. Collins JF, Bai L, Ghishan FK. The SLC20 family of proteins: dual functions as sodium-phosphate cotransporters and viral receptors. Pflugers Arch. 2004; 447(5): 647-652, doi: 10.1007/s00424-003-1088-x, indexed in Pubmed: 12759754.

42. Villa-Bellosta R, Sorribas V. Role of rat sodium/phosphate cotransporters in the cell membrane transport of arsenate. Toxicol Appl Pharmacol. 2008; 232(1): 125-134, doi: 10.1016/j.taap.2008.05.026, indexed in Pubmed: 18586044

43. Villa-Bellosta R, Sorribas V. Compensatory regulation of the sodium/phosphate cotransporters NaPi-IIc (SCL34A3) and Pit-2 (SLC20A2) during Pi deprivation and acidosis. Pflugers Arch. 2010; 459(3): 499-508, doi: 10.1007/s00424-009-0746-z, indexed in Pubmed: 19841935

44. Forster IC, Hernando N, Biber J, et al. Phosphate transport kinetics and structure-function relationships of SLC34 and SLC20 proteins. Curr Top Membr. 2012; 70: 313-356, doi: 10.1016/B978-0-12-394316-3.00010-7, indexed in Pubmed: 23177991.

45. Werner A, Kinne RK. Evolution of the Na-P(i) cotransport systems. Am J Physiol Regul Integr Comp Physiol. 2001; 280(2): R301-R312, doi: 10.1152/ajpregu.2001.280.2.R301, indexed in Pubmed: 11208556.

46. Fenollar-Ferrer C, Patti M, Knöpfel T, et al. Structural fold and binding sites of the human $\mathrm{Na}$-phosphate cotransporter NaPi-II. Biophys J. 2014; 106(6): 1268-1279, doi: 10.1016/j.bpj.2014.01.043, indexed in Pubmed: 24655502.

47. Villa-Bellosta R, Barac-Nieto M, Breusegem SY, et al. Interactions of the growth-related, type IIc renal sodium/phosphate cotransporter with PDZ proteins. Kidney Int. 2008; 73(4): 456-464, doi: 10.1038/sj.ki.5002703, indexed in Pubmed: 18046316.

48. Biber J, Gisler SM, Hernando N, et al. Protein/protein interactions (PDZ) in proximal tubules. J Membr Biol. 2005; 203(3): 111-118, doi: 10.1007/s00232-005-0738-7, indexed in Pubmed: 15986090

49. Forster IC, Loo DD, Eskandari S. Stoichiometry and $\mathrm{Na}+$ binding cooperativity of rat and flounder renal type II Na+-Pi cotransporters. Am J Physiol. 1999; 276(4): F644-F649, doi: 10.1152/ajprenal.1999.276.4.F644, indexed in Pubmed: 10198426.

50. Bacconi A, Virkki LV, Biber J, et al. Renouncing electroneutrality is not free of charge: switching on electrogenicity in a $\mathrm{Na}+$-coupled phosphate cotransporter. Proc Natl Acad Sci U S A. 2005; 102(35): 12606-12611, doi: 10.1073/pnas.0505882102, indexed in Pubmed: 16113079.

51. Segawa H, Kaneko I, Takahashi A, et al. Growth-related renal type II Na/Pi cotransporter. J Biol Chem. 2002; 277(22): 19665-19672, doi: 10.1074/jbc.M200943200, indexed in Pubmed: 11880379

52. Silverstein DM, Barac-Nieto M, Murer $\mathrm{H}$, et al. A putative growth-related renal $\mathrm{Na}(+)$-Pi cotransporter. Am J Physiol. 1997; 273(3 Pt 2): R928-R933, doi: 10.1152/ajpregu.1997.273.3.R928, indexed in Pubmed: 9321869.

53. Dinour D, Davidovits M, Ganon L, et al. Loss of function of NaPilla causes nephrocalcinosis and possibly kidney insufficiency. Pediatr Nephrol. 2016; 31(12): 2289-2297, doi: 10.1007/s00467-016-3443-0, indexed in Pubmed: 27378183

54. Hisano S, Haga H, Li Z, et al. Immunohistochemical and RT-PCR detection of $\mathrm{Na}+$-dependent inorganic phosphate cotransporter (NaPi-2) in rat brain. Brain Res. 1997; 772(1-2): 149-155, doi: 10.1016/s0006-8993(97)00884-6, indexed in Pubmed: 9406966.

55. Mulroney SE, Woda CB, Halaihel N, et al. Central control of renal sodium-phosphate (NaPi-2) transporters. Am J Physiol Renal Physiol 2004; 286(4): F647-F652, doi: 10.1152/ajprenal.00354.2002, indexed in Pubmed: 14644753

56. Albano G, Moor M, Dolder S, et al. Sodium-dependent phosphate transporters in osteoclast differentiation and function. PLoS One. 2015; 10(4): e0125104, doi: 10.1371/journal.pone.0125104, indexed in Pubmed: 25910236

57. Caverzasio J, Bonjour JP. Mechanism of rapid phosphate (Pi) transport adaptation to a single low Pi meal in rat renal brush border membrane. Pflugers Arch. 1985; 404(3): 227-231, doi: 10.1007/bf00581243, indexed in Pubmed: 4034369.

58. Biber J, Hernando N, Forster I, et al. Regulation of phosphate transport in proximal tubules. Pflugers Arch. 2009; 458(1): 39-52, doi: 10.1007/s00424-008-0580-8, indexed in Pubmed: 18758808.

59. Lötscher M, Kaissling B, Biber J, et al. Role of microtubules in the rapid regulation of renal phosphate transport in response to acute alterations in dietary phosphate content. J Clin Invest. 1997; 99(6): 1302-1312, doi: 10.1172/JCI119289, indexed in Pubmed: 9077540.

60. Traebert M, Roth J, Biber J, et al. Internalization of proximal tubular type II Na-P(i) cotransporter by PTH: immunogold electron microscopy. Am J Physiol Renal Physiol. 2000; 278(1): F148-F154, doi: 10.1152/ajprenal.2000.278.1.F148, indexed in Pubmed: 10644666

61. Beck L, Karaplis AC, Amizuka N, et al. Targeted inactivation of Npt2 in mice leads to severe renal phosphate wasting, hypercalciuria, and skeletal abnormalities. Proc Natl Acad Sci U S A. 1998; 95(9): 5372-5377, doi: 10.1073/pnas.95.9.5372, indexed in Pubmed: 9560283.

62. Burris D, Webster R, Sheriff $S$, et al. Estrogen directly and specifically downregulates NaPi-IIa through the activation of both estrogen receptor isoforms (ER and ER ) in rat kidney proximal tubule. Am J Physio Renal Physiol. 2015; 308(6): F522-F534, doi: 10.1152/ajprenal.00386.2014, indexed in Pubmed: 25608964

63. Shibasaki Y, Etoh N, Hayasaka M, et al. Targeted deletion of the tybe IIb $\mathrm{Na}(+)$-dependent Pi-co-transporter, $\mathrm{NaPi}-\mathrm{IIb}$, results in early embryonic lethality. Biochem Biophys Res Commun. 2009; 381(4): 482-486, doi: 10.1016/j.bbrc.2009.02.067, indexed in Pubmed: 19233126.

64. Corut A, Senyigit A, Ugur SA, et al Mutations in SLC34A2 cause pulmonary alveolar microlithiasis and are possibly associated with testicular microlithiasis. Am J Hum Genet. 2006; 79(4): 650-656, doi: 10.1086/508263, indexed in Pubmed: 16960801. 
65. Izumi S, Miyazawa H, Ishii K, et al. Mutations in the SLC34A2 gene are associated with pulmonary alveolar microlithiasis. Am J Respir Crit Care Med. 2007; 175(3): 263-268, doi: 10.1164/rccm.200609-1274OC, indexed in Pubmed: 17095743.

66. Hernando N, Myakala K, Simona F, et al. Intestinal Depletion of $\mathrm{NaPi}-\mathrm{IIb} /$ Slc34a2 in Mice: Renal and Hormonal Adaptation. J Bone Miner Res. 2015; 30(10): 1925-1937, doi: 10.1002/jbmr.2523, indexed in Pubmed: 25827490.

67. Bourgeois S, Capuano P, Stange G, et al. The phosphate transporter $\mathrm{NaPi}$-IIa determines the rapid renal adaptation to dietary phosphate intake in mouse irrespective of persistently high FGF23 levels. Pfluger Arch. 2013; 465(11): 1557-1572, doi: 10.1007/s00424-013-1298-9, indexed in Pubmed: 23708836.

68. Picard N, Capuano P, Stange G, et al. Acute parathyroid hormone differentially regulates renal brush border membrane phosphate cotransporters. Pflugers Arch. 2010; 460(3): 677-687, doi: 10.1007/s00424-010-0841-1, indexed in Pubmed: 20526720.

69. Segawa H, Onitsuka A, Kuwahata M, et al. Type IIc sodium-dependent phosphate transporter regulates calcium metabolism. J Am Soc Nephrol. 2009; 20(1): 104-113, doi: 10.1681/ASN.2008020177, indexed in Pubmed: 19056871.

70. Myakala K, Motta S, Murer H, et al. Renal-specific and inducible depletion of NaPi-IIc/Slc34a3, the cotransporter mutated in HHRH, does not affect phosphate or calcium homeostasis in mice. Am J Physiol Renal Physiol. 2014; 306(8): F833-F843, doi: 10.1152/ajprenal.00133.2013, indexed in Pubmed: 24553430.

71. Ewence AE, Bootman M, Roderick HL, et al. Calcium phosphate crystal induce cell death in human vascular smooth muscle cells: a potential mechanism in atherosclerotic plaque destabilization. Circ Res. 2008 103(5): e28-e34, doi: 10.1161/CIRCRESAHA.108.181305, indexed in Pubmed: 18669918.

72. Grases F, Sanchis P, Perelló J, et al. Effect of crystallization inhibitors on vascular calcifications induced by vitamin $D$ : a pilot study in Sprague-Dawley rats. Circ J. 2007; 71(7): 1152-1156, doi: 10.1253/circj.71.1152, indexed in Pubmed: 17587727.

73. Villa-Bellosta R, Bogaert YE, Levi M, et al. Characterization of phosphate transport in rat vascular smooth muscle cells: implications for vascular calcification. Arterioscler Thromb Vasc Biol. 2007; 27(5): 1030-1036, doi: 10.1161/ATVBAHA.106.132266, indexed in Pubmed: 17322102.

74. Bøttger P, Hede SE, Grunnet M, et al. Characterization of transport mechanisms and determinants critical for $\mathrm{Na}+$-dependent $\mathrm{Pi}$ symport of the PiT family paralogs human PiT1 and PiT2. Am J Physiol Cell Physiol. 2006; 291(6): C1377-C1387, doi: 10.1152/ajprenal.zh2-4590-corr.2006, indexed in Pubmed: 16790504.

75. Kakita A, Suzuki A, Nishiwaki K, et al. Stimulation of Na-dependen phosphate transport by platelet-derived growth factor in rat aortic smooth muscle cells. Atherosclerosis. 2004; 174(1): 17-24, doi: 10.1016/j. atherosclerosis.2003.12.039, indexed in Pubmed: 15135246.

76. Li X, Yang HY, Giachelli CM. Role of the sodium-dependent phosphate cotransporter, Pit-1, in vascular smooth muscle cell calcification. Circ Res. 2006; 98(7): 905-912, doi: 10.1161/01.RES.0000216409.20863.e7, indexed in Pubmed: 16527991.

77. Ravera S, Virkki LV, Murer H, et al. Deciphering PiT transport kinetics and substrate specificity using electrophysiology and flux measurements. Am J Physiol Cell Physiol. 2007; 293(2): C606-C620, doi: 10.1152/ajpcell.00064.2007, indexed in Pubmed: 17494632.

78. Farrell KB, Tusnady GE, Eiden MV. New structural arrangement of the extracellular regions of the phosphate transporter SLC20A1, the receptor for gibbon ape leukemia virus. J Biol Chem. 2009; 284(43): 29979-29987, doi: 10.1074/jbc.M109.022566, indexed in Pubmed: 19717569.

79. Salaün C, Rodrigues P, Heard JM. Transmembrane topology of PiT-2, a phosphate transporter-retrovirus receptor. J Virol. 2001; 75(12): 5584-5592, doi: 10.1128/JVI.75.12.5584-5592.2001, indexed in Pubmed: 11356966.

80. Giachelli CM, Speer MY, Li X, et al. Regulation of vascular calcification: roles of phosphate and osteopontin. Circ Res. 2005; 96(7): 717-722, doi: 10.1161/01.RES.0000161997.24797.c0, indexed in Pubmed: 15831823

81. Li X, Giachelli CM. Sodium-dependent phosphate cotransporters and vascular calcification. Curr Opin Nephrol Hypertens. 2007; 16(4): 325-328, doi: 10.1097/MNH.0b013e3281c55ef1, indexed in Pubmed: 17565274

82. Yoshiko Y, Candeliere GA, Maeda N, et al. Osteoblast autonomous Pi regulation via Pit1 plays a role in bone mineralization. Mol Cell
Biol. 2007; 27(12): 4465-4474, doi: 10.1128/MCB.00104-07, indexed in Pubmed: 17438129

83. Nowik M, Picard N, Stange G, et al. Renal phosphaturia during metabolic acidosis revisited: molecular mechanisms for decreased renal phosphate reabsorption. Pflugers Arch. 2008; 457(2): 539-549, doi: 10.1007/s00424-008-0530-5, indexed in Pubmed: 18535837.

84. Chien ML, Foster JL, Douglas JL, et al. The amphotropic murine leukemia virus receptor gene encodes a 71-kilodalton protein that is induced by phosphate depletion. J Virol. 1997; 71(6): 4564-4570, indexed in Pubmed: 9151850.

85. Kavanaugh MP, Miller DG, Zhang W, et al. Cell-surface receptors for gibbon ape leukemia virus and amphotropic murine retrovirus are inducible sodium-dependent phosphate symporters. Proc Natl Acad Sci U S A. 1994; 91(15): 7071-7075, doi: 10.1073/pnas.91.15.7071, indexed in Pubmed: 8041748.

86. Martinez FO, Sica A, Mantovani A, et al. Macrophage activation and polarization. Front Biosci. 2008; 13: 453-461, doi: 10.2741/2692, indexed in Pubmed: 17981560.

87. Willsky GR, Malamy MH. Characterization of two genetically separable inorganic phosphate transport systems in Escherichia coli. J Bacteriol. 1980; 144(1): 356-365, indexed in Pubmed: 6998957.

88. Fernandes I, Béliveau R, Friedlander G, et al. NaPO(4) cotransport type III (PiT1) expression in human embryonic kidney cells and regulation by PTH. Am J Physiol. 1999; 277(4): F543-F551, doi: 10.1152/ajprenal.1999.277.4.F543, indexed in Pubmed: 10516278.

89. Villa-Bellosta R, Ravera S, Sorribas V, et al. The Na+-Pi cotransporter PiT-2 (SLC20A2) is expressed in the apical membrane of rat renal proximal tubules and regulated by dietary Pi. Am J Physiol Renal Physiol. 2009; 296(4): F691-F699, doi: 10.1152/ajprenal.90623.2008, indexed in Pubmed: 19073637.

90. Beck L, Leroy C, Salaün C, et al Identification of a novel function of PiT1 critical for cell proliferation and independent of its phosphate transport activity. J Biol Chem. 2009; 284(45): 31363-31374, doi: 10.1074/jbc. M109.053132, indexed in Pubmed: 19726692

91. Salaün C, Leroy C, Rousseau A, et al. Identification of a novel transport-independent function of PiT1/SLC20A1 in the regulation of TNF-induced apoptosis. J Biol Chem. 2010; 285(45): 34408-34418, doi: 10.1074/jbc.M110.130989, indexed in Pubmed: 20817733.

92. Cecil DL, Rose DM, Terkeltaub R, et al. Role of interleukin-8 in PiT-1 expression and CXCR1-mediated inorganic phosphate uptake in chondrocytes. Arthritis Rheum. 2005; 52(1): 144-154, doi: 10.1002/art.20748, indexed in Pubmed: 15641067.

93. Mansfield K, Teixeira CC, Adams CS, et al. Phosphate ions mediate chondrocyte apoptosis through a plasma membrane transporter mechanism. Bone. 2001; 28(1): 1-8, doi: 10.1016/s8756-3282(00)00409-9, indexed in Pubmed: 11165936

94. Beck L, Leroy C, Beck-Cormier S, et al. The phosphate transporter PiT1 (Slc20a1) revealed as a new essential gene for mouse liver development. PLoS One. 2010; 5(2): e9148, doi: 10.1371/journal.pone.0009148, indexed in Pubmed: 20161774

95. Crouthamel MH, Lau WL, Leaf EM, et al. Sodium-dependent phosphate cotransporters and phosphate-induced calcification of vascular smooth muscle cells: redundant roles for PiT-1 and PiT-2. Arterioscler Thromb Vasc Biol. 2013; 33(11): 2625-2632, doi: 10.1161/ATVBAHA.113.302249, indexed in Pubmed: 23968976.

96. Wallingford MC, Gammill HS, Giachelli CM. Slc20a2 deficiency results in fetal growth restriction and placental calcification associated with thickened basement membranes and novel CD13 and laminin 1 expressing cells. Reprod Biol. 2016; 16(1): 13-26, doi: 10.1016/j.repbio.2015.12.004, indexed in Pubmed: 26952749

97. Wang C, Li Y, Shi L, et al. Mutations in SLC20A2 link familial idiopathic basal ganglia calcification with phosphate homeostasis. Nat Genet. 2012; 44(3): 254-256, doi: 10.1038/ng.1077, indexed in Pubmed: 22327515 .

98. Jensen N, Schrøder HD, Hejbøl EK, et al. Loss of function of Slc20a2 associated with familial idiopathic Basal Ganglia calcification in humans causes brain calcifications in mice. J Mol Neurosci. 2013; 51(3): 994-999, doi: 10.1007/s12031-013-0085-6, indexed in Pubmed: 23934451.

99. Hilfiker $\mathrm{H}$, Hattenhauer $\mathrm{O}$, Traebert $\mathrm{M}$, et al. Characterization of a murine type II sodium-phosphate cotransporter expressed in mammalian small intestine. Proc Natl Acad Sci U S A. 1998; 95(24): 14564-14569, doi: 10.1073/pnas.95.24.14564, indexed in Pubmed: 9826740. 